cornea, (kerato)conus posticus, allows the condition of keratoconus to supervene. The common association of eczema and hay-fever with keratoconus may be explained by the assumption that these diseases provide the stimulus for eye-rubbing.

\section{Summary}

Thirty-two patients with eczema, half of whom had the atopic variety, were discovered among 100 patients with keratoconus10 times the expected number.

Many patients who develop keratoconus have an inherited defect of the posterior cornea-(kerato)conus posticus. Eczema, hay-fever, or emotional disturbance provides the stimulus that causes excessive eye-rubbing, and this may result in conical distortion of the cornea-keratoconus.

Keratoconus should be suspected in young eczematous patients whose vision suddenly deteriorates.

I would like to thank Mr. Frederick Ridley, who freely granted me the full facilities of his department and helped me with this survey, Mr. M. Rubin, who discussed many of the patients with me, and Dr. P. F. Borrie, who gave me access to his personal notes of 45 patients who had consulted him at Moorfields Hospital, City Road, for eczema ; none of these had keratoconus.

\section{REFERENCES}

Akesson, H. O. (1964). Acta med. scand., 175, 115. Bobroff, A. (1962). Eczema, its Nature, Cure, and Prevention. Thomas, Springfield, Illinois.

Brunsting, L. A., Reed, W. B., Bair, H. L. (1955). Arch. Derm., 72, 237.
Butler, T. H. (1930) Trans, Ophthal Soc, U.K. 50, 551

Carr, R. D., Berke, M., and Becker, S. W. (1964).' Arch. Derm., 89, 27. Cullen, J. F., and Butler, H. G. (1963). Brit. F. Ophthal., 47, 321.

Davson, H. (1963). The Physiology of the Eye, 2nd ed., p. 52. Churchill, London.

Delthil, S., and Julou, J. (1963). Ann. Oculist. (Paris), 196, 409.

Dohlman, C. (1964). Arch. Ophthal., 71, 254.

Duke-Elder, W. S. (1938). Textbook of Ophthalmology, vol. 2, pp. 1280, 2027. Kimpton, London.

Franceschetti, A., and Caronnes, A. V. (1960). Bull. Soc. belge Ophtal., $124,896$.

François, J. (1961). Ann. Derm. Syph. (Paris), 88, 397.

Hall, D. A. (1961). The Chemistry of Connective Tissue, p. 58. Thomas, Springfield, Illinors.

Hilgartner, H. L., Hilgartner, H. L., jun., and Gilbert, J. T. (1937). Amer. 7. Ophthal., 20, 1032.

Hogan, M. J. (1952). Trans. Amer. Ophthal. Soc., 50, 265

Mann, I. C. (1957). Developmental Abnormalities of the Eye, 2nd ed. British Medical Association, London.

Masci, E., and Scullica, L. (1962). Boll. Oculist., 41, 350.

Readett, M. D. (1964). Brit. 7. Derm., 76, 126.

Ridley, F. (1961). Brit. 7. Ophthal., 45, 631, 832

Ridley, F. (1961). Brit. F. Ophthal., 45, 631, 832. logy Clinics. Little, Brown, Boston, Mass.

Richardson, J. S. (1963). Connective Tissue Disorders, pp. 10, 18. Blackwell, Oxford.

Rosen, E. (1959). Atopic Cataract. Thomas, Springfield, Illinois.

Roth, J. L., and Kierland, R. R. (1964). Arch. Derm., 89, 209.

Service, W. C. (1939). 7. Amer. med. Ass., 112, 2034.

Solomon, L. M. (1964). Canad. med. Ass. 7., 90, 644.

Spencer, W. H., and Fisher, J. J. (1959). Amer. F. Ophthal., 47, 332.

Stallard, P. L. (1930) Trans. Ophthal. Soc U.K. 50,556

Sulzberger, M. B. (1954). In L. J. A. Lowenthal's The Eczemas. Livingstone, London

Teng, C. C. (1963). Amer. 7. Ophthal., 55, 18.

Thomas, C. I. (1955). The Cornea, p. 238 . Thomas, Springfield, Illinois. Tips, R. L (1954) Amer. F. hum. Genet., 6, 328.

van Walbeek, K. (1960). In Transparency of the Cornea-a Symposium, edited by S. Duke-Elder and E. S. Perkins, p. 58. Blackwell, Oxford.

Waardenburg, P. J., Franceschetti, A., and Klein, D. (1961). Genetics and Ophthalmology, p. 452. Blackwell, Oxford

Weber, R. G., Roth, G. M., and Kierland, R. R. (1955). F. invest. Derm., $24,19$.

Weiss, L., and Dingle, J. T. (1964). Ann. rheum. Dis., 23, 57.

\title{
Some Unusual Cases of Defibrination in Pregnancy
}

\author{
JAMES WILLOCKS,* M.D., M.R.C.o.G. ; JOHN MACVICAR, $†$ M.D., M.R.C.o.G.
}

Defibrination in obstetrics is commonly regarded as being associated with extensive abruptio placentae; amniotic fluid embolism, and intrauterine death of the foetus. The defibrination syndrome, however, may also occur in more unusual cases, and obstetricians should always be on the look-out for this phenomenon. The following three cases, which have occurred in our hospital during the last eight months, serve to illustrate this.

\section{Case 1. Defibrination Associated with Mixed Accidental Haemorrhage. Reversal of Defibrination and Continuation of Pregnancy}

A woman aged 23 had a bad obstetric history. She had living children from her first two pregnancies, but the second child required exchange transfusion because of rhesus iso-immunization. Her third pregnancy ended in abortion at 23 weeks: the foetus was hydropic.

In her fourth pregnancy she had a severe mixed accidental haemorrhage at 28 weeks. She required transfusion with 5 pints (2.8 litres) of blood, and was delivered by lower-segment caesarean section. The child weighed $1 \mathrm{lb}$. $9 \mathrm{oz}$. (710 g.) and lived only one and a half hours: it was hydropic.

* Lecturer, Department of Midwifery, University of Glasgow, The Queen Mother's Hospital, Glasgow.

t Senior Lecturer, Department of Midwifery, University of Glasgow, The Queen Mother's Hospital, Glasgow.
In her fifth pregnancy she was admitted with severe vaginal bleeding at 26 weeks. The uterus felt rather tense and a diagnosis of revealed accidental haemorrhage was made. The fihrinogen titre was 1 in 2 as compared with the normal 1 in 128 (Sharp et al., 1958). This represents approximately $1 / 60$ of the normal fibrinogen level-that is, $5-10 \mathrm{mg} . / 100 \mathrm{ml}$. of clottable fibrinogen. Two pints (1.1 litres) of triple-strength plasma and $8 \mathrm{~g}$. of fibrinogen were given as well as 2 pints (1.1 litres) of blood.

Two hours later the fibrinogen titre was normal, and remained so on repeated testing. There was no further bleeding and the pregnancy continued.

The rhesus antibody titre was 1 in 128 anti-D and 1 in 64 anti-C by Coombs on admission. At 33 weeks antibodies to both $\mathrm{C}$ and $\mathrm{D}$ were present, 1 in 512 by Coombs. (The patient's husband's blood was homozygous rhesus-positive.)

At this time ( 33 weeks) the foetal heart was noted to be slow and irregular, and lower-segment caesarean section was carried out. A live female child weighing $3 \mathrm{lb}$. $11 \mathrm{oz}$. (1,670 g.) was delivered. The placenta was situated in the upper segment of the uterus. There was a mass of solid yellowish blood clot at one edge of the placenta, occupying about one-quarter of the placental surface: the overlying placental tissue was completely infarcted. The placenta weighed $400 \mathrm{~g}$. and the wet weight of the retroplacental clot was $87 \mathrm{~g}$. after lysing as much of the entrapped blood as possible. Bleeding was not troublesome during the operation and the fibrinogen titre was normal.

The baby required repeated exchange transfusions but progressed well. The mother was discharged on her tenth post-operative day. 


\section{Case 2. Defibrination Associated with Placenta Praevia}

A woman aged 35 was admitted at 34 weeks in her second pregnancy on account of slight, painless vaginal bleeding. Clinical and radiological examination suggested placenta praevia. Fibrinogen estimation on admission was normal. At 36 weeks, after recurrent small haemorrhages, she lost about $8 \mathrm{oz}$. $(225 \mathrm{ml}$.) of fresh blood per vaginam, and it was decided that delivery was necessary. At operation the presence of an anterior placenta praevia, type II, was confirmed, and the baby, a live female weighing $5 \mathrm{lb}$. $(2,270 \mathrm{~g}$.), was delivered by lower-uterine-segment caesarean section. The placenta was removed manually. There was no evidence of abruptio. After repairing the uterine muscle with two layers of continuous stitches in the usual manner it was noticed that bleeding was still troublesome and was poorly controlled by understitching. A pack was inserted and brought out through the abdominal wound, after peritonization of the lower segment, in an attempt to obtain reasonahle haemostasis. A specimen of blood taken during operation was noted to clot. Blood loss was estimated at 5 pints (2.8 litres), and this was replaced by transfusion.

An hour after operation the patient's general condition was satisfactory, the blood-pressure being $115 / 75 \mathrm{~mm}$. $\mathrm{Hg}$ and the pulse $102 / \mathrm{min}$. She then suddenly collapsed, becoming pale, restless, and dyspnoeic, and the pulse rate rose to 120 . A large superficial haematoma was noted in the abdominal wall and there was free bleeding from the stitch line. The fibrinogen titre was nil, indicating an almost complete afibrinogenaemia. Blood transfusion was continued as well as a rapid infusion of 1 pint $(570 \mathrm{ml}$.) of triplestrength plasma, followed by $10 \mathrm{~g}$. of fibrinogen. Calcium gluconate, 2 g., was also given. After this the fibrinogen titre returned to normal, and remained so. Clinically the patient's condition improved quite rapidly and remained satisfactory. A total of 11 pints (6.25 litres) of blood was transfused.

The abdominal pack was removed 42 hours after operation and there was no further bleeding. The wound healed satisfactorily.

Examination of the blood on the fifth day showed evidence of megaloblastic anaemia. Treatment with folic acid was instituted with satisfactory result. The patient's haemoglobin was $13.1 \mathrm{~g} . /$ $100 \mathrm{ml}$. on the 28 th day, when she went home with her baby.

This appeared to be a case of fibrinogen depletion, but, in addition, lotting tests performed before and after fibrinogen was given showed evidence of probable fibrin breakdown products. These may have been due to a preceding fibrinolytic episode.

\section{Case 3. Defibrination Associated with Jaundice in Pregnancy}

A woman aged 22 was admitted at 38 weeks in her second pregnancy with a history of vomiting of one week's duration and jaundice over the previous 12 hours. On examination she was markedly jaundiced. Her blood-pressure was $130 / 100 \mathrm{~mm}$. Hg and there was albumin in the urine. Liver-function tests suggested obstructive jaundice, the alkaline phosphatase being 42.5 KingArmstrong units per $100 \mathrm{ml}$. and the thymol turbidity less than 1 unit. Total bilirubin was $12.5 \mathrm{mg} . / 100 \mathrm{ml}$.

The patient complained of vague lower-abdominal discomfort and she was slightly tender over the lower pole of the uterus, which was enlarged consistent with the dates. The vertex was presenting and the foetal heart was clearly heard. On account of the uterine tenderness and the signs of pre-eclamptic toxaemia the possibility of a minor degree of abruptio placentae was considered, although there was really very little evidence to suggest this. Bloodcoagulation tests were done and the fibrinogen titre was nil. No significant fibrinolysis or circulating anticoagulant was demonstrated. In view of these findings $8 \mathrm{~g}$. of fibrinogen was given intravenously and the clotting tests were repeated on completion of this treatment. The fibrinogen titre was now normal ( 1 in 128) and again there was no evidence of fibrinolysis. The tests were also normal in a further specimen 12 hours later.

Examination of a peripheral blood film revealed the presence of a probable folic-acid deficiency. Treatment was instituted accordingly.

Twenty-four hours after admission labour began, ending six and hilf hours later with the spontaneous vertex delivery of a live male child weighing 7 lb. $6 \mathrm{oz}$. (3,345 g.). The placenta was malivered three minutes after the child with a blood loss of $250 \mathrm{ml}$. delivered three minutes after the placenta showed no evidence whatsoever of abruptio.
During the first five days of the puerperium the patient remained hypertensive $(140 / 100 \mathrm{~mm}$. $\mathrm{Hg}$ ) and was markedly oedematous. The jaundice persisted but there was no albuminuria. The patient passed pale stools, and the clinical and biochemical findings were persistently indicative of obstructive jaundice.

By the 13 th day the jaundice was very slight. $X$-ray examination of the abdomen showed no evidence of opaque calculi in the gallbladder area. The liver function gradually reverted to normal. The serum transaminases were never significantly raised. The oedema disappeared and the blood-pressure was normal $(110 / 70 \mathrm{~mm}$. $\mathrm{Hg}$ ) when the patient was dismissed with her baby on the 14 th day. When seen at the post-natal clinic she was well and a cholecystogram showed a normal biliary tree with good emptying after a fatty meal. No calculi were demonstrated.

\section{Discussion}

Three obstetric cases are presented which have only one feature in common-the defibrination syndrome. None of them illustrates the classical association between abruptio placentae and defibrination except the first, which was unusual in that the clotting defect was fully and permanently corrected without interrupting the pregnancy. 'This contradicts the commonly held belief that the clotting defect persists until delivery. (Termination of pregnancy is emphasized as one of the main principles of the management of these cases by Ingram et al. (1960).) The amount of defibrination in this case was corroborated by examining the placenta at delivery, when $87 \mathrm{~g}$. of tough retracted retroplacental clot was found which must have contained many grammes of fibrin. This is in accord with Nilsen's (1963) statement that fibrin in retroplacental clots is usually sufficient to account for fibrinogen depletion.

In the second patient defibrination occurred in a case of placenta praevia. The association of these two conditions is usually thought to be rare. Donaldson (1964) stated that there were only 12 such cases in the literature, but Phillips (1964) reported that seven cases of placenta praevia had occurred in 105 cases of obstetric hypofibrinogenaemia which she had studied during the past 10 years. In the case here reported the association with haemorrhage appears to be clear, but whether the haemorrhage from placenta praevia was the ultimate aetiology is less clear. The delay of about two hours between removal of the placenta and the development of the full-blown clinical picture of defibrination makes it difficult to implicate the placenta as the main cause: perhaps the trauma of operation and the profuse loss of blood from vessels in the uterus was also a factor. This would be similar to the blood-clotting defect found after major surgery such as excision of the rectum, currently attributed to fibrinolysis (McNicol, 1962), thus differing from the coagulation defect in abruptio placentae, which is not usually caused by fibrinolysis (Nilsen, 1963).

Blood-clotting defects are also known to be associated with severe liver damage (Sherry et al., 1959), but the degree of liver disease in Case 3 was slight and there was no evidence of fibrinolysis, which might be expected with liver disease. 'No satisfactory explanation can be put forward for the defibrination which occurred in this patient.

\section{Conclusions}

(1) Though defibrination is a comparatively rare occurrence in obstetrics the practising obstetrician should always be aware of the possibility even in atypical cases.

(2) It was found possible by the use of fibrinogen to reverse the syndrome in all the cases described. In a case of accidental haemorrhage which occurred at a time when the foetus was extremely premature, pregnancy was continued for a further seven weeks and a live birth resulted. It may be that early diagnosis and timely reversal of the blood-clotting defect may improve the prognosis for both mother and baby in these cases. 


\section{Summary}

Three cases of the defibrination syndrome in pregnancy are reported: one occurred in association with abruptio placentae at 26 weeks, another in association with caesarean section for placenta praevia at 36 weeks, and the third in association with jaundice at 38 weeks. In all cases the clotting defect was reversed by the use of fibrinogen and all mothers and babies survived. The importance of timely diagnosis and treatment of the defibrination syndrome, even in unusual obstetric situations, is stressed.

We should like to thank Professor Inn Donald for permission to publish these cases, and also Dr. M. L. N. Willoughby, under whose direction the blood tests were done and who has given us much helpful advice.

\section{REFERENCES}

Donaldson, I. A. (1964). F. Obstet. Gynaec. Brit. Cwlth, 71, 126. Ingram, G. I. C., Norris, P. R., and Tanner, E. I. (1960). Ibid., 67, 367. McNicol, G. P. (1962). Scot. med. F., 7, 266.

Nilsen, A. (1963). Acta obstet. gynec. scand., 42, Suppl. No. 2, p. 1.

Phillips, L. L. (1964). Abstracts Xth Congress of the International Society of Haematology, Stockholm, G. 88.

Sharp, A. A., Howie, B., Biggs, R., and Methuen, D. T. (1958). Lancet, 2, 1309.

Sherry, S., Fletcher, A. P., and Alkjaersig, N. (1959). Physiol. Rev., 39. 343.

\title{
Complications and Death in Chicken-pox
}

\author{
A. W. BLAIR, ${ }^{*} \dagger$ M.B., CH.B., D.C.H. ; W. M. JAMIESON,* M.D., F.R.C.P.ED., D.P.H. \\ G. H. SMITH,* T.D., M.D., F.C.PATH.
}

Brit. med. F., 1965, 2, 981-983

Chicken-pox is usually a mild disease in which complications are uncommon and death is rare. We wish to record two fatal cases in relation to the same small village outbreak involving between 20 and 30 children; the first of these patients (Case 1) died from encephalitis, and the second (Case 2) as a result of haemorrhagic complications. About the same time, but unrelated to the village outbreak, we observed two further patients (Cases 3 and 4) with haemorrhagic manifestations in relation to chicken-pox, each of whom made a good recovery.

\section{Case 1}

A boy aged 8 years fell ill on Christmas Day 1962, and next day developed a rash. During the ensuing few days he began to vomit, complained of " tiredness in the head," became delirious, and in the evening of 28 December was admitted to hospital. After admission he was extremely restless and consciousness was lost. Signs of meningeal involvement were absent; deep reflexes were slightly exaggerated, and there was clonus of the right ankle; the pupils were dilated but equal, and optic fundi were normal. There was a generalized rash which had the characteristic distribution and features of chicken-pox. Examination of other systems revealed no abnormality. Cerebrospinal fluid contained 11 lymphocytes per c.mm. ; protein was $30 \mathrm{mg} . / 100 \mathrm{ml}$. and sugar $58 \mathrm{mg} . / 100 \mathrm{ml}$. A diagnosis of chicken-pox encephalitis was made.

The boy was sedated with paraldehyde, which controlled the extreme restlessness, but, although his colour remained good, respiration was rapid and stertorous. He continued in this uneasy state for several hours, but during the night his condition deteriorated further ; his temperature rose to $105^{\circ} \mathrm{F}$. $\left(40.6^{\circ} \mathrm{C}\right.$.), and the pulse weakened. Steroid therapy was begun, but he died about nine hours after admission to hospital, and less than four days from the onset of symptoms.

Virological study was not carried out, but material from the rash in siblings was reported as showing "multinucleated giant cells as typically seen in varicella, herpes, and zoster."

The main necropsy findings, apart from the rash, were in the brain and liver. Gross enlargement and swelling of the brain, which weighed 1,600 g., was very striking. The surface vessels

* King's Cross Hospital רd Department of Pathology, Maryfield Hospital, Dundee.

† Now Registrar, The Hospital r Sick Children, Great Ormond Street, London. showed intense congestion, but there was no evidence of meningitis. Microscopical examination of numerous blocks from cortex, medulla, and mid-brain confirmed gross oedema, and revealed marked active hyperaemia and perivascular haemorrhages. The basal ganglia and mid-brain grey matter showed early degenerative changes in some neurones and some satellitosis along with mononuclear infiltration, but this was not pronounced, and perivascular cuffing was not observed. These changes are frequently seen in virus encephalitis, and the degree of change is often surprisingly small. Demyelination was not demonstrated by either the Marchi or the Weigert-Pal method. The liver was enlarged, pale, and greasy ; microscopical examination showed gross fatty. change and areas of focal necrosis with mononuclear infiltration, and an acidophil intranuclear inclusion body was demonstrated. In the areas of focal necrosis small aggregates of fibrin strands were observed. The lesions in the liver appeared to be older than might have been expected from the duration of symptoms.

\section{Case 2}

A boy aged $3 \frac{1}{2}$ years developed a rash on 2 January 1963, and the following day his parents noticed areas of bruising on both thighs. There was no history of pre-existing bleeding disorders in the patient or in other members of his family. He was admitted to hospital, and was found to have a generalized vesicular rash typical of chicken-pox. The lesions were sparse, and some of the vesicles on the trunk had haemorrhage into them. In addition to the rask there were areas of redness and lividity on the thighs. By 5 January these discoloured areas had increased in size, and the thighs were swollen. At this stage the haematological findings were as follows: haemoglobin 6.6 g. $/ 100 \mathrm{ml}$.; white blood count, 6,600/c.mm. (polymorphs $50 \%$, lymphocytes $37 \%$, atypical monocytes $13 \%$ ) ; platelets $35,000 /$ c.mm.; Hess test negative. His condition deteriorated rapidly, and he appeared pale and shocked; the systolic bloodpressure was $90 \mathrm{~mm}$. The thighs were by this time considerably swollen and painful, and there was a large effusion, presumably haemarthrosis, into the left hip-joint. The haemoglobin had fallen to $3.9 \mathrm{~g} . / 100 \mathrm{ml}$. ; the prothrombin time was over five minutes, and no fibrinogen could be detected in the blood. Transfusion had been started with packed cells, and when the fibrinogen lack was discovered he was given $2 \mathrm{~g}$. of fibrinogen by slow infusion, the transfusion then being continued with whole blood. On the morning of 7 January he died.

Virological study was negative for smallpox, and material from the lesions showed multinucleated giant cells as typically seen in chicken-pox. 